\title{
Cubo
}

\section{Andreia Cardoso}

Faculdade de Ciências da Universidade do Lisboa andreia_a.cardoso86@hotmail.com

\section{CITAÇÃO}

Cardoso, A. (2014)

Cubo,

Rev. Ciência Elem., V2 (01):111.

doi.org/10.24927/rce2014.111

\section{EDITOR}

José Ferreira Gomes,

Universidade do Porto

\section{RECEBIDO EM}

21 de maio de 2012

\section{ACEITE EM}

21 de setembro de 2012

\section{PUBLICADO EM}

24 de setembro de 2012

\section{COPYRIGHT}

(C) Casa das Ciências 2019.

Este artigo é de acesso livre, distribuído sob licença Creative

Commons com a designação CC-BY-NC-SA 4.0, que permite a utilização e a partilha para fins não comerciais, desde que citado o autor e a fonte original do artigo.

\section{rce.casadasciencias.org}

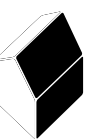

Cubo. do gr. kúbos, "cubo", pelo lat. cubu

Cubo é um poliedro regular com 6 faces.

\section{Notas}

Um cubo tem 6 faces, 12 arestas, 8 vértices.

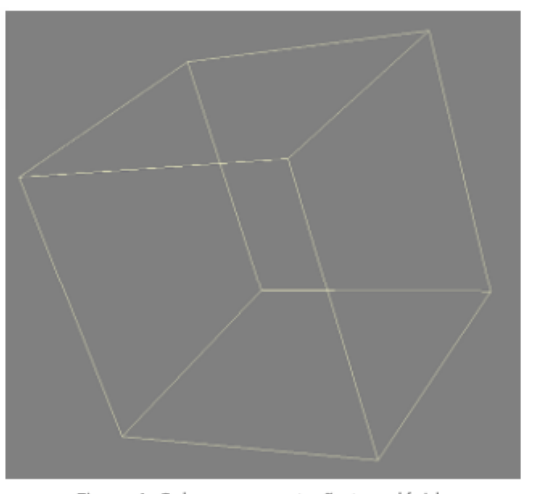

Figura 1. Cubo, representação translúcida

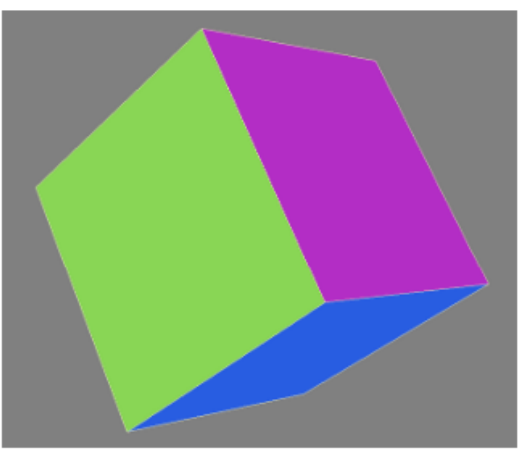

Figura 2. Cubo, representação opaca

O cubo, juntamente com o dodecaedro, o tetraedro, o octaedro e o icosaedro constituem os Sólidos Platónicos.

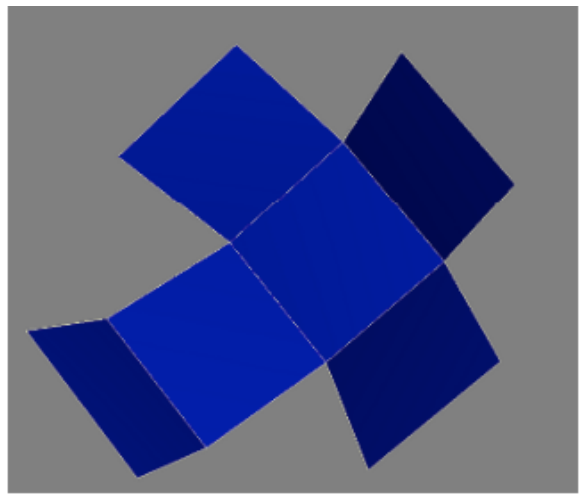

Figura 3. Cubo em planificação

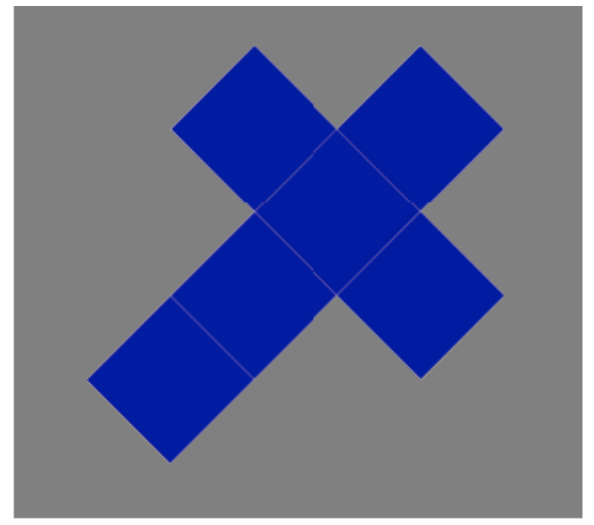

Figura 4. Cubo planificado

As faces do cubo são quadrados.

0 dual do cubo é o octaedro e reciprocamente. 